\title{
Mapping of Green Buying Perception in Developing Country
}

\section{Dr. Tanti Handriana}

\author{
Faculty of Economics and Business, Universitas Airlangga, Indonesia \\ Email: tanti.handriana@feb.unair.ac.id
}

\section{Doi:10.5901/mjss.2016.v7n3p19}

\begin{abstract}
This study aims to gather information and analyze in-depth about the public perception on the green buying in Indonesia. The analysis focus on each of the community groups, ie group of professionals, group of housewives, and group of young people. These three groups are expected to represent the green buying behavior of today's society. Research is conducted by using qualitative research approach, using the technique of in-depth interviews in data collection. This study finds that people have different 'green' buying behavior. Professional groups are the groups most concerned in it, while the groups who are less concerned with green buying are groups of housewives, normally they reasoned that the purchase of green products are very expensive. The great expectation for environmentally conscious and green buying behavior is on groups of young people (students). Generally, young people have a great desire to behave in green if later they are already working and earning enough to buy green products which are generally more expensive than the regular products. Future expectations are that these research findings can be used as a reference by the government in environmental policy making, as well as benefits to the company/organization in offering products that are environmentally friendly.
\end{abstract}

Keywords: green buying, qualitative research, in-depth interviews, behavior intention, developing country

\section{Introduction}

In this century, the threats to the environment of the earth slid so swift, the decreasing availability of natural resources, the depletion of the ozone layer, and the narrowing of farmland. As one of the solutions is that consumers began to switch to environmentally friendly behavior, for example by means of transport and household products that are environmentally friendly. One type of environmentally conscious behavior will be called as environmentally consumerism or green buying.

Meanwhile, in terms of marketers are green marketing terms. According to Polonsky (1994), green marketing or environmental marketing consists of all activities designed to generate and facilitate any exchanges, which are intended to meet the needs or desires of man, such as the need for satisfaction with minimum adverse impacts on the natural environment. Thus, increased environmental awareness and concern seems to be the driving force for policy makers in the field of marketing to adopt new marketing practices. Meanwhile, Schlegelmilch et al. (1996) classifies green product into public green products, recycled paper products, products not tested on animals, environmentally friendly detergents, organic fruits and vegetables, ozone friendly aerosol, and energy-saving products.

Currently, green marketing strategy is the new spell for marketers to produce recycled products, the non-toxic product and environmentally friendly products to meet customer needs, and to have this benefit on a large scale (Patil, 2012). Until now, studies on green buying behavior in Indonesia are relatively few, as well as buying green behavior among young people or teenagers, housewives and professionals are still not widely studied. Therefore, this study will explore and analyze in depth about the public perception on the purchase of green products (green buying) in Surabaya.

To get the comprehensive research findings, this research will study the perceptions of different groups communities, among other groups of professionals, young people and housewives. As disclosed by Harris et al. (2000) in Kaufmann et al. (2012) that environmentally conscious consumers are the white, the women, the professionals, and the youth. The professionals are viewed as group of people who are educated and have well established of economic aspect. Meanwhile the groups of young people are groups of people with a sizeable amount who are potential to build a strong collective force in society for environmental protection. Young people are more ready than the older generation to accept new ideas and innovative (Ottman et al., 2006), and that supporters of environmental protection tend to be younger in age (Schwepker and Cornwell, 1991). Meanwhile, the last groups namely housewives are the spearhead in household purchases, so that their contribution to the green buying is very large. Therefore the aim of this study is to mapping the perception of green buying in Indonesia, as well as to analyze in depth through three informant groups, namely professionals, young people and housewives. 


\section{Literature Review}

\subsection{Green Marketing}

Green marketing which is a continuing marketing is defined as an effort by the company to design, promote, determine the price, distribute and promote the products with regard to environmental protection means (Polonsky, 2011). Green marketing has been defined as all activities designed to generate and facilitate any exchanges intended to satisfy human needs or wants, in order to provide satisfaction, with minimal adverse impacts on the natural environment by Polonsky (2011). Meanwhile, Saini (2013) explained that green marketing is the process of selling goods and/or services based on environmental benefits, where the solely goods or services are environmentally friendly as well as the manufactured products and/or packaged in an environmentally friendly way.

From the mid of 1990s, consumers started to become more and more environmentally friendly and socially conscious (Strong, 1996). During this period, critical consumers began to emerge as a new force green consumerism, they need the social responsibility from companies (Gurau and Ranchhod, 2005). Meanwhile, green consumers are defined as people who avoid products that may endanger the health of consumers or the others; causing significant damage to the environment during manufacture, disposal, consuming a disproportionate amount of energy; causing unnecessary wastage, using ingredients derived from endangered species or the environment (Strong, 1996). While Sharma (2011) explained that the green consumer focuses on the following activities: purchase of products, such as detergents, which have a reduced environmental impact; avoiding the products with aerosol; purchasing recycled paper products (such as toilet tissue and paper for writing); buying organic products; buying locally produced food; buying from a local store; looking for products using less packaging; and using their own bags instead of using plastic provided by the store.

Meanwhile, the benefits of green marketing that can be felt by the organization/company as the producer of products/services, among others: (1) to ensure long-term sustainable growth with profitability; (2) to save money in the long term, although at first it took a huge cost; (3) to help companies to sell their products and services by keeping in mind their environmental aspects; (4) to assist in accessing new markets and enjoying a competitive advantage; (5) The majority of employees also feel proud and responsible to work for an environmentally responsible company (Saini, 2013).

Green marketing is done by the company to increase the level of awareness and to show that people are worried about the environment can do something to solve some problems (Cherian and Jacob, 2012). Meanwhile, Saini (2013) explains that a product can be claimed as a 'green' products if they meet the following criteria: (1) saving water and energy; (2) preventing the pollution contributes to air, water and soil; (3) protecting the indoor air quality; (4) using renewable raw materials; (5) producing little environmental impact; (6) being produced by means of environmentally consciousness; and (7) using their own bags, instead of carrying a plastic provided by the store.

\subsection{Green Buying}

Green buying is defined as the purchase and consumption of products that are friendly/beneficial to the environment. Elkington (1994) defines green consumers as behavior that avoid products that are likely to endanger the health of consumers or others, not causing significant damage to the environment, energy usage for advertising in a proportionate amount, harmless waste, not using ingredients derived from the endangered species or environment.

Kim and Choi (2005) in Kaufmann (2012) explains that the public attention to environmental issues gradually but surely increased during the three decades since the beginning of Earth Day, that is the public interest to preserve nature and biodiversity. Meanwhile, Cherian and Jacob (2012) revealed that raising awareness on environmental issues has caused a shift in the way consumers view about their lives. There has been a change in consumer attitudes towards green life style. People actively attempt to reduce their impact on the environment. However, this is not widespread and still growing. Organizations and businesses have seen a change in the attitude of consumers and strive to gain the advantage in competitive market by exploiting the potency in the green market industry.

\section{Methodology}

The approach which will be used in this study is a qualitative research, which collecting the data by using in-depth interview technique. The reasons for the use of qualitative research approaches as they relate to the research objectives, namely to make mapping and analyzing in depth the green buying behavior of people in developing countries. The purpose of these studies would not be satisfactory results when carried out research with a quantitative approach. This 
approach is used to explore in detail and in-depth information on the public perception of green buying in Surabaya, Indonesia. Strauss and Corbin (1990), as well as the advice given by Mostafa (2006), that in order to identify green behavior, then on subsequent research will be carried out through in-depth interviews, can also be carried out through focus group discussions. The informants in this study were grouped into three (3) categories, among others: (1) groups of professional; (2) groups of housewives; and (3) groups of young people (students) in Surabaya, Indonesia. In all of the three groups of informants, it has been conducted in-depth interviews in May 2015 in Indonesia.

\section{Result and Discussion}

Discussion of the research finding analysis on public perception on green buying is based on constructs that are perceived by groups of informants, namely (1) Groups of Professionals; (2) Groups of Housewives; and (3) Groups of young generation. While the constructs are (a) familiarity; (b) the perception of the company; (c) response to environmentally friendly products; (d) experience of green product purchase; (e) information resources; ( $f$ ) the type of purchased product; (g) suggestions for the government; (h) advice for companies; (i) consumer affective factors; (j) the surrounding people behavior; $(k)$ purchase intent/intention to purchase green products in the future. Here the constructs will be discussed respectively.

From the finding of in-depth interview with professionals the perception of professionals on green buying behavior was obtained the following findings:

\subsection{Familiarity}

The professionals generally are already very familiar with the term of green products (environmentally friendly products) and the term of green buying/green purchasing (buying green products/environmentally friendly products).

I often hear the term...

I've heard the term of green product, even often...

Meanwhile, groups of housewives have a positive perception on the purchase of environmentally friendly products. Although generally they are less familiar with green products and green buying.

I ever heard, but I do not understand...

It seems I've never heard the term...

I've ever heard, when I studied in the university, it had been described by the profession...

As for all the informants from groups of young people (students) have known / have been familiar with the term of green product and the terms of green buying /green purchasing.

I've ever heard it, more precisely l often hear it...

I've heard the term of green products...

\subsection{Perception of the company}

Positive perception is from the professionals to the companies that produce environmentally friendly products. The company's concern to the health of consumers and the environment is still the underlying principles of their business, even though the main goal is still to make a profit.

I think the company is the one which thinks about the future, because in developed countries people are already aware of the health and the environment, so mostly they consume environmentally friendly products. And I'm sure in Indonesia will be similar in the future, to...

I think it means that companies are admirable, as they already think far ahead...

I agree and have similar thought with these companies, like my restaurant this rice also uses organic rice...

Not much different from the perception of the professional group, the group of housewives also has a good perception on companies that produce green products.

.... Yes. It means that the companies intend to seek big profit, because it is based on information which I had that the 
price of environmentally friendly products must be expensive.

I think the company already think ahead, it means that the company also concern the environment, yes, because the companies are not careless in manufacture the products, but also think of consumers, the environment, and even the future of our children and grandchildren later...

Yes I perceive positively and have a good purpose, which means that companies concern environmental issues as well... products.

Meanwhile all of the students have a positive response on companies that produce environmentally friendly

I think such company is the clever one in viewing business opportunity, because currently there are not lot of companies / businesses having such orientation, generally companies only produce ordinary products that are already saturated in the market, for example, opened a restaurant, yes in common restaurant, not the restaurant which products are from organic ones...

My response is certainly yes... I personally give an appreciation to the companies said, because the company has been contributing to the environment, the company is not carelessly to get profit in he business. If all businessmen think in such a way, so the damage of the environment such as global heating can be prevented ...

I think the company is included in the category of innovative company, has differentiation in the products it produces...

\subsection{The Response to the environmentally friendly products}

The response of the professionals on environmentally friendly products, they generally have a positive response.

Thank God, in the past few years my family and I have switched to consumption of environmentally friendly products... As a consumer, I am satisfied with environmentally friendly products that I've bought over the years, and as a businessman based on environmentally friendly raw materials, now I also feel happy, because it has been many suppliers of rice who offer me organic rice, so it helps my business become smooth certainly...

Positive responses were also given by housewives on environmentally friendly products, although most participants have not become green products consumers, price factor comes into housewife's consideration in buying green products.

I think it is good, but until now I have not become a buyer of the products, as far as I know the price of their products relatively more expensive...

Yes I like, lately there have been more and more environmentally friendly products. The common purchased products among others are lights, organic fruits and vegetables, perfume, and cosmetics...

Yes, good product surely, but what about the price? Certainly expensive, isn't it?...

Meanwhile, the response of the students in environmentally friendly green products is as follows:

I think it's a very good thing, but until now I have not become consumers of such products...

For environmentally friendly products, my response is positive, although I have not become a consumer...

The environmentally friendly products are generally high quality ones, so it is usually followed by high prices of the product...

\subsection{Green product purchasing experience}

The professionals mostly experienced buying the environmentally friendly products.

My family and I-yes- often buy eco-friendly product...

I've bought environmentally friendly products, but I do not include as loyalist...

Until now I get used to buy usual products without the environmentally friendly frills, but once or twice I went along with

friends to buy organic fruits and vegetables in market over there....

Compared with my colleague, I am including a category that I often buy environmentally friendly products...

Associated with the habit to buy environmentally friendly products, it seems most of the informants of housewife group said that they have never purchased, and a small amount of them get used to buy it.

Until now I've never bought, I get used to buy items regardless of whether it is environmentally friendly goods or not.... 
In my opinion, the products are necessary to consume option and use by all Indonesian people. Because I am a housewife who generally makes purchases for most of our household needs, so the housewife likes me who should be aware of the need to consume products that are environmentally friendly. But yes again, because the price of the products was relatively expensive, so the effect is that not much housewives who buy it, including me...

For groups of teenagers, very few who have made a purchase of green products, the main reason is the limited money they have.

I have never bought environmentally friendly products, because usually the price is expensive...

Until now I have never bought the products it...

\subsection{Sources of Information}

Stated by Schlegelmilch, et al. (1996) that the establishment of consumer attitudes on the environment require consideration of the sources of personal information (such as family and friends) and impersonal sources of information (eg. media channel). The resources of professionals to obtain information about environmentally friendly products generally come from the mass media and social media.

On the internet, social media, TV, in an environment where I work, principally there are many sources of information...

From friends where I work I, watching TV, the Internet, reading newspapers, FB, and other...

Internet, TV, social media, in the workplace environment, friends or my colleagues, my community too...

From my work place environment, the internet, literature, TV, many sources because right now there are resources

everywhere and at any time we can access...

Meanwhile, the housewife gets information about green products from media, from close people (husband), and from their social activities.

When I watched TV, also listen to the radio...

Many, from social media, reading newspapers, watching TV, husband, etc...

Many sources of information, from TV, newspapers, internet, etc....

The information on environmentally friendly products is generally obtained by young people from more sources of information compared with groups of professionals and housewives. Sources among others came from the Internet, schools / colleges, social media, and the mass media.

From the internet, lecture / literature, TV, friends, family, social networks, and other sources...

From family, internet, friends, from social media, TV...

Many sources, it's now the information era. The main source is from the internet, literature, off line and in line friends...

\subsection{Types of purchased products}

Schlegelmilch et al. (1996) classifies green product into public green products, recycled paper products, products not tested on animals, environmentally friendly detergents, organic fruits and vegetables, ozone friendly aerosol, and energysaving products. The eco-friendly products which are often consumed by professionals relatively varied.

Organic rice, organic fruits, my wife cosmetics, household supplies, and others....

Perfumes, and other household items....

Organic rice for the purposes of the restaurant and home, organic fruits, cosmetics toiletres and wife and children also...

Meanwhile, because volume purchases of green products by housewives is still relatively low compared with professional groups, so that the variety of products consumed by housewives are relatively limited.

Food / beverage products, toiletry products and also cosmetics...

I've never, but it is not often to buy ... occasionally buy detergent completely rinse, buy LED lights... 


\subsection{Suggestions for the government}

Suggestions will be given to the government by the professionals related to environmentally friendly products, in essence, they ask the government to be more concerned with policies related to the environment.

The government should appreciate the people and companies that have been involved in environmentally friendly product...

Government need to socialize the consumption of environmentally friendly products program to the public at large...

The government should give support to companies that already produce environmentally friendly products...

Input and suggestion will be given to government related to environmentally friendly products by the housewife group who focus more on subsidies to consumers, policy-making related to environmentally friendly products, and the need for socialization.

The government should give subsidies on the price for the public in order that the environmentally friendly goods are not too expensive...

Perhaps the government through RT/RW encourages calls for the use of environmentally friendly products...

The Government might make policies to facilitate the companies that produce environmentally friendly products, and also provide subsidies to the public so that more people will become consumers of such products...

The young generation is the generation that is expected to have a much larger concern than the older generation (professionals and housewives). The preservation of the earth and its contents need a helping hand and concerns of adolescents and youth. The suggestions for the government related to environmentally friendly products which provided by the students are as follows:

If I may suggest to the government, I want the government more concerned with businesses that produce environmentally friendly products, especially in SMEs, for example, by giving the ease with facilities or may be by giving subsidy...

The government may be more concerned with the company as manufacturers of environmentally friendly products, for example by giving a reward, so that companies are increasingly motivated to operate...

My hope is that the government give full support to these companies, such as the government provide ease of licensing, and the government can roll out loans without interest to the company or precisely to the SMEs that produce environmentally friendly products...

\subsection{Suggestions for the company}

The suggestions given by professionals on the companies that produce goods and companies that produce services related to environmentally friendly products are more rational, than the advice given by groups of housewives.

For these companies, they should always adhere to the principles of environmentally friendly products, which means that the company works according to the rules, do not deceive the public, for instance they said that these are environmentally friendly products, but in reality the usual products promoted as environmentally friendly products, with the main objective to get a big profit...

Offering products at affordable prices...

My hope for the company or the businessmen of environmentally friendly products is consistent in maintaining the quality of its products...

The suggestion will be given to the businessmen related to environmentally friendly products that companies may offer an affordable price, and that the company could continue to maintain consumer trust.

My hope is that these companies can offer a price that is not too expensive to be affordable by the whole society. So that people like me are also able to buy...

In order that the company can maintain public trust in their credibility as a company that produces environmentally friendly products. It means that companies have to be honest, for example, if the company says that the product is an organic product, it is indeed the production process and their products really follow the rules as environmentally friendly products...

Hopefully I hope the companies will constantly exist, even growing. In addition, the company to intensify further promotion in cooperation with the NGO environmentalists for example, so that more people are aware of the importance of consuming eco-friendly products.... 
Young people are not less good compared to the suggestions given by professionals in providing suggestion for businessmen that manufacture environmentally friendly products.

I hope they can work with credible, meaning that the company does not perform public deception. It means that the produced product was really environmentally friendly products, not ordinary products are packaged or labeled environmentally friendly...

My suggestions that the company should be more innovative in producing, for example by learning the similar products abroad...

I think businessmen should also promote its products more aggressively, of course, by looking for a cheap alternative media campaign, for example, through word of mouth or word of mouth through social media, for example facebook, blogs, instagram, and so on...

\subsection{Affective consumer factors}

Affective/feelings factors which are in the minds of the professionals after becoming the consumers of environmentally friendly products, generally they are happy and satisfied with what they consume during this time.

\section{Feelings of pleasure and calm...}

There is a sense of satisfaction and pride to be a customer of environmentally friendly products...

Feeling of pleasure and pride...

Meanwhile, from group of housewives, their affective factors are not so visible, due to the limited volume of consumption of green friendly products in this group. It is not much distinct from what is perceived by informants of group of students.

I felt there was a bit of relief, because I started to get used to my family members to live a healthy life... Since becoming a consumer of environmentally friendly products, I feel there is a sense of pride in ourselves, and also feel less guilty related to environmental contamination or false on ourselves for I had consumed a product that is "destructive" to my body...

\subsection{Action to the surrounding people}

Word of mouth (WOM) which is positive on the surrounding people is as a real action done by professional groups.

During this time I also often recommend my friends, colleagues, best friends, and family to become a consumer of environmentally friendly products...

One day when I work well established, God willing I will be a loyal consumer of environment-friendly products, and I will suggest to friends and family to become consumer of environmentally friendly products as well...

In my work, I have been called friends as provocateur of organic products and a healthy lifestyle, because I always suggest and ask my friends to a healthy lifestyle as well care for our environment...

Not much different from the professional group, the group of housewives also intends to carry out WoM although the scope of the target is less than professional groups.

Even in every chance I try to encourage them to care for the environment, starting from consuming environmentally friendly products...

I will inform them about the environmentally friendly products, though only at the beginner stage, ha ha... products.

Likewise, the student groups will also do the same thing namely inviting people around them to consume green

One day when I work well establishedly, God willing I will be a loyal consumer of environment-friendly products and I will suggest to friends and family to become consumer of environmentally friendly products as well...

\subsection{Intention to buy/intention to purchase green products in the future}

Based on the theory of reasoned action proposed by Ajzen and Fishbein (1974), the intention is considered as an important factor in the relationship between attitudes and behavior. Associated with the professionals' intention to 
buy/keep buying green products in the future, most of the informants intend to buy or buy the products again.

Definitely (will) buy again...

Yes, of course buy again...

God willing I will keep buying in the future...

The intention of the housewife group to buy green products, it appears that almost all intend to buy, although in reality at this time this group is still not much in buying environmentally friendly products.

I have intention to buy goods if the price is affordable by my purse...

God willing, I will keep consuming the products...

God willing, if there is sustenance, let all of my family healthy and the environment will be well maintained...

In the long term, the teen group is a group of potential target market for green products. It shows from their future intentions to buy these products.

There is a desire to buy, but when I work, have my own money...

There is an intention to buy the products, but not in the near future, because now I get the from my parents, ha ha...

There is (an intention), but not now, maybe later when I'm settled in my work...

Green consumers are described as consumers who avoid products that endanger the health, cause damage to the environment, cause pollution or excessive discharge (Mainieri et al., 1997). Based on the explanation of interviews with the informants above, it is added that each member of the group has similarities in perception of green buying. Professional group is a group of the most "literate" by green buying. Meanwhile, green consumers are described as consumers who avoid products that endanger the health, cause damage to the environment, cause pollution or excessive discharge. So the green consumer will: boycott products that are not environmentally friendly, and are willing to pay more for green products.

From various angles of analysis, this group does have a sequence of number one. Based on the income earned, this group is the most of its revenue, so that their buying power is also highest. While based on the understanding of green product, this group is also the most familiar and the most care. This group also dominates the volume of buying of green products, followed by housewives, and the last group of teenagers. This is in accordance with a study conducted by Rokicka (2002) that the consumer who has the higher level of knowledge of the environment of pro-environmental behavior are the much better. Consumers with higher level of education will be able to access more information, so it will be more aware of the environment. Likewise, the level of income, such as the findings of a study conducted by Berkowitz and Lutterman (1968) and Henion (1972) showed that consumers with middle and high incomes with higher levels of education are more likely tend to behave pro-environment.

For the time being, the exact target market for green products is professional group. They become the most potential market. These groups are making use of social media (television, newspapers, and magazines), social networking, and co-workers to get information on environmentally friendly products. The positive response was given by a group of professionals on products and companies that produce environmentally friendly products. The type of product that has been bought/purchased by a group of informants is quite varied, ranging from household goods, food, body care products such as perfume, as well as environmentally-friendly products that are used for business purposes by this group. Meanwhile word of mouth (WOM) is performed positively by informants from the professional group of people around them. WoM is an effective means of communication for the introduction and promotion of environmentally friendly products. It is in accordance with the definition of WOM that product information is carried out by one individual to another (Solomon, 2015).

This group experiences a great concern for the environment; they argued that if businessmen have a concern for the environment, then damage of environment such as global warming will not happen. Meanwhile, related to the government's policy on environmental protection as well as the motivation for businessmen is the suggestion given by professional group to the government. Meanwhile, affective factors on the purchase of green products in the professional group shows to give pleasure and satisfied for what they consume during this time. Satisfaction plays an important role in shaping the loyalty of this professional group. Satisfaction is defined as someone's happy or disappointed feeling after they compared between expectation and performance of products that have been bought (Kotler and Keller, 2016). Associated with satisfaction and loyalty, the loyalty of a group of professionals is clearly visible from the informal presentation that in the future they will continue to buy environmentally friendly products that have been bought over the 
years.

The next is the informants of housewives. From study conducted by Meinairi et el. (1997) obtained the findings that women have a higher significance level than the men in the green buying aspect and environmental attitude scale. This group has a positive response toward the products and companies that produce environmentally friendly products. Although most informants from this group have never bought the green products for the time being. Generally, the reason of why they have not consumed the products is due to the price factor of environmentally friendly that generally makes the product more expensive compared with conventional products. Therefore, this group suggests the producers of environmentally friendly products to be able to offer lower-priced products. Likewise, the advice given by these groups to the government, that the government should provide subsidies for society to buy the green products, also suggested by this group to activate the role of civil society organizations (Pillars of Citizens, the Neighborhood) to make people aware of the importance of behaving to care environment.

The informants from the group of housewives have the high will and intention to buy environmentally friendly products, with a note that the price offered is not too expensive. Meanwhile, although the degree of familiarity of this group toward the terms of green buying and green consumer is relatively low, but their concern to do WoM is quite high, although the scope of target is not as wideas professional. Associated with sources of information on environmentally friendly products, informants from group of housewives get more information from social media such as television, from the neighborhood, and family (husband).

Lastly, the informants are group of students. This group is the best target market that needs to be targeted by the businessmen that produces environmentally friendly products. A positive response on the products and companies that produce green products is also showed by this group, although in real terms, this group is still at the level of cognitive and affective, has not reached the (buying) behavior, as in the Theory of Reasoned Action (TRA). TRA is a social psychological theory that has been acknowledged, which states that a specific belief affect the behavioral perception and actual behavior. Similarly, research conducted by Schlegelmilch et al. (1996) also obtain the findings in his research that the attitude towards the environment is a major determinant of the environmentally oriented buying behavior.

Suggestions given by the students to the companies that get the highest green products so that companies are that companies must be more innovative, always maintain the trust that has been given by the customer, to socialize on consumers with more aggressively, and the government should also more concern with businessmen that produce environmentally friendly products, especially in SMEs, for example, being given with the ease of facilities or subsidies, as well as the ease of licensing, granting rewards for businessmen who have a concern for the environment. Meanwhile, students get information on green products and green consumers from various sources, among others the internet, lecture/literature, TV, friends, family, social media (Facebook, Twitter, Path, etc.). Thus, this research findings can also be used by the marketers of products with the young people target market, the marketers should pay attention to the behavior of today's young people in consuming environmentally friendly products. The marketers can also offer the products with based on the concept of green marketing, the environmentally friendly product by targeting the youth as its target market.

The marketing management experts and environmentalist activists also agrees with the perception of green buying in all three groups of informants, that the green product concept will be followed by green buying/green purchasing. The issue of global warming and the destruction of the earth increasingly echoed in almost all over the world, making the concept of green buying into one of the solutions.

The findings of the research conducted by Verhoef (2005) in Germany show that the consumers in buying organic meat products based on good economic motives, as well as emotional motives. Meanwhile, green buying phenomenon in developed countries and in developing countries indicates different conditions. In developed countries, most people are already aware of the importance of maintaining their personal and family health, as well as keep the environment through their consumption patterns. Meanwhile, in developing countries in general education level of society is still low, so that the awareness of personal and family health and preserving the environment has not been the top priority. The main priorities of the people of developing countries generally are that the importance is to eat well. It can not be separated from the amount of income per capita in developed countries and in developing countries in which the difference is very large, so that the buying power of developing countries is also far below the people's buying power in developed countries.

In addition to the different aspects of per capita income which are striking between the people of developed countries and the people of developing countries, the culture the people in developed countries also differ from the culture of the people in developing countries. As we know that the culture inherited from generation to generation of parents, families, and communities, to encourage people in developing countries to meet consumption needs and the needs of his family with the principle of 'The essential is to survive'. The principle that form the behavior and lifestyles healthy which is unhealthy and do not care about the environment. 
The interesting thing that happened in developing countries is especially the people who live in urban areas -where they are included in the upper middle class-, the last few years they are more and more aware of the importance of living a healthy life and care about environmental sustainability. The principle generally arises because they realize that the cost to the hospital for treatment is much more expensive than when they are living a healthy life, namely by running concept of the green buying / green purchasing.

From the findings of the studies on green buying (Mainieri et al., 1997) and Schlegelmilch et al., 1996), it obtained the findings that: (1) women have a higher significance level than men in the two aspects of green buying and environmental attitude scale; (2) age, income, and education are not associated with the 10 attitudes and behavior variables; (3) middle class society has the sincerity in their stance on the general environment, and (4) as a consequence, the practitioners need to take into account that consumerism environment can be enhanced by strengthening consumer confidence over the pro-environment, or by increasing the structural factors (availability, provision label, the ability to provide products that are environmentally friendly), or by both.

For people who are aware of the importance of protecting the environment, will generally be reflected in their behavior and lifestyle. Starting from the things that are simple to the addictive behavior to always keep the environment. For example, from the behavior of littering candy wrappers, by not littering candy wrappers littering carelessly, but they keep it for a while in a pocket or insert a candy wrapper into their bags. Understanding and behavior to keep the environment should receive serious attention from all parties, namely the manufacturers (companies) which produced the environmentally friendly products, as well as from the consumer side, by consuming these products, as well as government policies and regulations, then the threat of environmental damage will be able to be minimized.

Healthy lifestyle and keeping the surrounding environment are the two-goals from consumers who consume green products. In developed countries, the government fully supports the behaving 'green' policy, government make policies and regulations that restrict people's behavior which damage the environment, for example in Japan, farmers will grow crops, it is forbidden to use plastic to inhibit the growth of grass which interfere the plant, While in our country, people are still free and unrestricted use plastic to ease their activity. Though plastic waste is waste that is very difficult to recycle, even it took hundreds of years for melting process to the ground. Thus, environmentally conscious behavior comes not only from each person but also very much need to be supported by the government.

\section{Conclusion \& Implication}

In summary, the finding of developing country's perception mapping is divided into three groups of informants (professionals, housewives, and young people), as shown in the following table.

Table of Research Findings Resume

\begin{tabular}{lccc}
\hline No. Constructs & Profesional & Housewife & Young People \\
\hline 1. Familiarity & Very Familiar & Less Familiar & Familiar \\
2. Perception of the company & Positive & Positive & Positive \\
3. Response to the environmentally friendly products & Positive & Positive & Positive \\
4. Experience the buying of green products & Often & Rarely & Not Yet \\
5. Source of Information & Many sources & Many sources & Many sources \\
6. Type of bought products & Varirous & Limited & Not Yet \\
7. Suggestions for Government & Need & Need & Need \\
8. Suggestions for Companies & Good & Good & Good \\
9. Consumer affective factors & Goog & Good & Good \\
10. Surrounding people's action & Positive WoM & Positive WoM & Positive WoM \\
11. Intention to buy & Intend & Intend & Intend \\
\hline
\end{tabular}

From the research findings, it was found that the people have the different 'green' behavior. Group of professional is the most concerned group in it, while the group which is less concerned with green buying is a group of housewives, normally they reasoned that the purchase of green products are very expensive. Great expectations for environmentally conscious and green buying behavior are on young people (students). Generally, young people have a great desire to behave in green if later they work and earn enough to buy green products which are generally more expensive than the regular products (not environmentally friendly ones).

The concerns of their personal and family health, and concern for the environment make the demand for environmentally friendly products from day to day show the improvement. This condition can be captured as a business opportunity for producers of green products. Meanwhile, the contribution that can be given from this study in the 
development of marketing in particular the concept of green marketing and green buying, specially in developing countries, that is not only a group of professionals who have concern of green product, but also group of housewives have interest similarly, although in the real buying behavior on environmentally friendly products is still relatively small. Likewise, the young people have a great contribution in green buying and green marketing are worthy to note for the success of implementing the green buying concept in the future.

The first suggestion that can be given from this study is for the government. The Government should provide good support and protection to businessmen and to consumers of green products, by making law or policy/regulation. Subsidy for businessmen and for consumers is also highly desirable, so that environmentally friendly products can be reached not only by the upper classes, but also reached by the middle and lower classes. Likewise for businessmen who have a good performance, they deserves to get a reward from the government.

The second suggestion is given to the businessmen. The opportunity to offer environmentally friendly products is very large. From the three groups as informants in this study, it shows that the three groups have the intention to buy green products in the future. Continuous innovation needs to be done by businessmen to produce innovative green products at affordable prices to consumers (especially for group of housewives). Meanwhile, on the minds and thoughts of the young people group, there has been awareness of the need to live healthy by consuming green products, but not yet reached to the stage of behavioral, due to financial limitation. This could be observed by the businessmen to make them as potential target markets.

Finally, the suggestions fo further researcher, they can conduct a study on green consumer behavior based on demographics (gender, age, race, domicile: village/city), in order to get a clearer description of the research informant/respondent. I also suggest that future research will conducted with quantitative approach, both with surveys and experimental methods, to determine the factors that influence consumer buying intent on environmentally friendly products in developing countries. Because the findings of this research are that the three groups of informants (professionals, housewives, and young people), showed equally intention to buy environmentally friendly products in the future.

\section{References}

Ajzen, I., \& Fishbein M. (1974). Factors Influencing Intentions and The Intention-Behavior Relations. Human Relations, Vo. 27 (January), 1-15.

Berkowitz, L., \& Luterman K. (1968). The Traditionally Socially Responsible Personality. Public Opinion Quarterly, 32, 169-185.

Chen, T. B., \& Chai L. T. (2010). Attitude towards the environment and the green products: consumers' perspective. Management Science and Engineering, 4, 27-39.

Cherian J., \& Jacob J. (2012). Green Marketing: A Study of Consumers' Attitude towards Environment Friendly Products. Asian Social Science, 8(12), 117-126.

Henion, K. E. (1972). The Effect of Ecologically Relevant Information on Detergent Sales. Journal of Marketing Research, 9, 10-14.

Gurau, C., \& Ranchhod A. (2005). International Green Marketing: A Comparative Study of British and Romanian Firms. International Marketing Review, 22(5), 547-61.

Kaufmann, H. R., Panni M. F. A. K., \& Orphanidou Y. (2012). Actors Affecting Consumers' Green Purchasing Behavior: An Integrated Conceptual Framework. Amfiteatru Economic, XIV(31), 50-69.

Kotler, P., \& Keller K. L. (2016). Marketing Management. 15th ed., New York: Pearson.

McEachern, M., \& McClean P. (2002). Organic Purchasing Motivations and Attitudes: Are they ethical? International Journal of Consumer Studies, 26, 85-92.

Mainieri, T., Barnett E. G., Barnett E. G., Valdero T. R.; Unipan J. B., \& Oskamp S. (1997), Green Buying: The Influence of Environmental Concern on Consumer Behavior. The Journal of Social Psychology, 137(2), 189-204.

Mostofa M. M. (2006). Antecedents of Egyptian Consumers'Green Purchase Intentions: A Hierarchical Multivariate Regression Model. Journal of International Consumer Marketing, 19(2), 97-126.

Ottman, J. A., Stafford E. R., \& Hartman C. L. (2006). Avoiding Green Marketing Myopia: Ways To Improve Consumer Appeal For Environmentally Preferable Products. Environment, 48(5), 22-36.

Patil, V. G. (2012). Green Marketing: Myths \& Facts. Golden Research Thoughts, 1, 1-8.

Polonsky M. J. (1994). An Introduction to Green Marketing. Electron Green Journal. 1(2), 1-10.

Polonsky, M. J. (2011). Transformative green marketing: Impediments and opportunities. Journal of Business Research, 64(12), 13111319.

Rokicka, E. (2002). Attitudes Towards Natural Environmen. International Journal of Sociology. 32(2), 78-90.

Saini, B. (2013). Green Marketing and Its Impact on Consumer Buying Behaviour. International Journal of Engineering Science Invention, 2(2), 61-64.

Schlegelmilch, B. B., Bohlen G. M., \& Diamantopoulos A. (1996). The Link Between Green Purchasing Decisions and Measures of Environmental Consciousness. European Journal of Marketing, 30(5), 35-55. 
Schwepker, C.H. Jr., \& Cornwell T. B. (1991). An Examination of Ecologically Concerned Consumers and Their Intention to Purchase Ecologically Packaged Products. Journal of Public Policy \& Marketing, 10, 77-101.

Sharma, Y. (2011). Changing Consumer Behaviour with Respect to Green Marketing - A Case Study of Consumer Durable and Retailing. International Journal of Multidisciplinary Research, 1(4), 152-162.

Schlegelmilch, B. B., Bohlen G. M., \& Damantopoulos A. (1996). The Link Between Green Purchasing Decisions and Measures of Environmental Consciousness. European Journal of Marketing, 30(5), 35-55.

Solomon, M. R. (2015), Cunsumer Behavior, Buying, Having, and Being, $3^{\text {th }}$ ed., Boston: Pearson.

Strauss, A. L., \& Corbin, J. (1990). Basics of Qualitative Research: Grounded Theory Procedures and Techniques, Newbury Park, CA: Sage Publications.

Strong, C. (1996). Features Contributing to The Growth of Ethical Consumerism: a Preliminary Investigation, Marketing Intelligence \& Planning, 14(5), 5-13.

Tan B. C., \& Lau T. C. (2011). Green Purchase Behavior: Examining the Influence of Green Environmental Attitude, Perceived Consumer Effectiveness and Specific Green Purchase Attitude. Australian Journal of Basic and Applied Sciences, 5(8), 559-567.

Verhoef, P. C. (2005). Explaining Purchases of Organic Meat by Dutch Consumers. European Review of Agricultural Economics, 32(2), 245-267.

Wong, V., Turner, W., \& Stoneman, P. (1996). Marketing strategies and Market Prospects for Environmentally-Friendly Consumer Products. British Journal of Management, 7(3), 263-81. 